\title{
Betonarme Binaların Tepki Spektrumu ve Doğrusal Elastik Zaman Tanım Alanında Analizleri
}

\author{
Emrah Meral ${ }^{*}$ \\ 1* Osmaniye Korkut Ata Üniversitesi, Mühendislik Fakültesi, İnşaat Mühendisliği Bölümü, Osmaniye, Türkiye, (ORCID: 0000-0002-7635-0432), \\ emrahmeral@osmaniye.edu.tr
}

(Uluslararası Araştırma-Geliştirme ve Tasarım Konferansı - 15-18 Aralık 2021)

(DOI: 10.31590/ejosat.1045545)

ATIF/REFERENCE: Meral, E. (2021). Betonarme Binaların Tepki Spektrumu ve Doğrusal Elastik Zaman Tanım Alanında Analizleri. Avrupa Bilim ve Teknoloji Dergisi, (32), 215-220.

$\ddot{O} \mathbf{z}$

$\mathrm{Bu}$ çalışmada betonarme binaların tepki spektrumu ve doğrusal elastik zaman tanım alanında analizlerinden bulunan taban kesme kuvveti ve deplasman talepleri karşılaş̧tırılmıştır. Bu sebeple 2-, 4- ve 7- katlı 3-B binalar 2007 Türk Deprem Yönetmeliği’ne göre oluşturulmuştur. Binaların X ve Y yönlerinde toplam 78 analiz yapılarak taban kesme kuvveti, tepe noktası ötelenme oranı ve maksimum göreli kat ötelenme oranı gibi parametreler hesaplanmıştır. Sonuçlara göre iki analiz çeşidi arasındaki talepler 2- ve 7katlı binalarda farklılık gösterirken 4- katlı binada birbirine oldukça yakın değerler elde edilmiştir. Her iki analizde de kat sayısının artışına bağlı olarak deplasman taleplerinin arttığı ve incelenen binalar içinde 7- katlı binaların daha riskli olduğu görülmüştür.

Anahtar Kelimeler: Zaman tanım alanında analiz, Tepki spektrumu analizi, Betonarme binalar.

\section{Linear Time History and Response Spectrum Analyses of RC Buildings}

\begin{abstract}
The base shear force and displacement demands which obtained from response spectrum and linear time history analysis of the reinforced concrete buildings were compared in this study. Therefore, 2-, 4- and 7-storey 3-D buildings were created according to the 2007 Turkish Earthquake Code. A total of 78 analyzes in the $\mathrm{X}$ and Y directions of the buildings were performed to calculate the parameters such as base shear force, roof drift ratio and maximum interstory drift ratio. According to the results, while the demands between the two types of analysis differed in 2- and 7-storey buildings, very close values were obtained each other in the 4-storey building. In both analyzes, displacement demands increased depending on the increment in the number of storey and 7-storey buildings were found to be riskier in examined buildings.
\end{abstract}

Keywords: Time history analysis, Response spectrum analysis, Reinforced concrete buildings.

\footnotetext{
* Sorumlu Yazar: emrahmeral@,osmaniye.edu.tr
} 


\section{Giriş}

Yapıların deprem davranışının belirlenebilmesi için doğrusal elastik veya doğrusal elastik olmayan analiz yöntemleri kullanılmaktadır. $\mathrm{Bu}$ yöntemler de yapıların sismik taleplerinin elde edilebilmesi için statik ve dinamik olarak ayrılmaktadır. Yapıların deprem taleplerinin tahmininde doğrusal olmayan zaman tanım alanında analiz gerçekçi sonuçlar vermesine karşın, doğrusal olmayan modellerin hazırlanmasındaki zorluklar ve analizlerin işlem hacmi bu yöntemin uygulanmasını sinırlandırmaktadır. $\mathrm{Bu}$ yüzden doğrusal elastik ve doğrusal elastik olmayan statik ya da eşdeğer tek serbestlik derecesine çevrilerek yapılan doğrusal elastik olmayan zaman tanım alanında analiz yöntemleri tercih sebebi olmaktadır. Ayrıca, tepki spektrumu ve doğrusal elastik zaman tanım alanında analiz yöntemleri de sismik taleplerin hesabında kullanılmaktadır. Literatürde betonarme yapılarda doğrusal elastik zaman tanım alanında analiz ve tepki spektrumu analizi yöntemleri kullanılarak yapılmış çeşitli çalışmalar bulunmaktadır. Doğrusal elastik ve elastik olmayan zaman tanım alanında analizlerden bulunan tepe noktası deplasman taleplerinin karşılaştırılmasında, doğrusal elastik analiz sonuçlarının 2- ve 4- katlı binalarda doğrusal elastik olmayan analiz sonuçlarına göre düşük olduğu, 7-katlı binalarda birbirine yakın olduğu bulunmuştur (İnel ve ark., 2011). İleri yönlenme etkisine sahip ve farklı zeminler üzerinde kaydedilen deprem ivme kayıtlarıyla yapılan 2-, 4- ve 7- katlı binaların doğrusal elastik zaman tanım analizlerinde, katlar arasında taban kesme kuvveti oranı açısından çok fark bulunmamakla birlikte kat sayısının artmasıyla taban kesme kuvveti taleplerinin nispeten azaldığı ve genel olarak deplasman taleplerinin kat sayısıyla doğru orantılı olarak değiştiğ gözlemlenmiştir (Önür, 2011). İki (2-B) ve üç (3-B) boyutlu 10-, 15- ve 20- katlı bina modellerinin doğrusal elastik ve elastik olmayan zaman tanım alanında analizlerinde, 2 -B ve 3-B 10katlı binaların periyodunun 2-B ve 3-B 15- ve 20- katlı binalara göre birbirine yakın olmasından dolayı 2-B doğrusal olmayan 10-katlı binaların doğrusal modelleriyle temsil edilebileceği ve bunun yanında 3-B doğrusal 15- ve 20- katlı binalarda daha düşük deplasman talepleri elde edildiği sonuçlarına varılmıştır (Özer ve ark., 2017). Perdeli çerçeve ve çerçeve sisteme sahip 5-, 10- ve 15- katlı binaların tepki spektrumu analizi ile bulunan kat ivmelerinin ve göreli kat ötelenmelerinin doğrusal olmayan zaman tanım alanında modal analiz ile bulunan değerlerden daha düşük çıkabileceği gösterilmiştir (Özdemir, 2016). Öz değer analizi, tepki spektrumu analizi, statik analiz, statik itme analizi, dinamik analiz yöntemleri kullanılarak 5- katlı betonarme bina için maksimum tepe noktası deplasmanı ve taban kesme kuvveti gibi parametreler hesaplanmıştır (Velioğlu, 2017). Yöntemlerin birbirleri ile tutarlılığını ortaya koymak adına elde edilen sonuçlar karşılaştırıldığında, zaman tanımlı analizlerde hesaplanan deplasman değerlerinin birbirine yakın olduğu ve taban kesme kuvvetinin en büyük değerine statik itme analizinde ulaşıldığı görülmüştür (Velioğlu, 2017).

Çalışmanın amacı düşük ve orta katlı betonarme binaların taban kesme kuvveti ve deplasman taleplerini tepki spektrumu ve doğrusal elastik zaman tanım alanında analiz yöntemleri ile belirlemektir. $\mathrm{Bu}$ amaç 1şı̆̆ında düşük ve orta katlı mevcut betonarme binaların temsili için 2-, 4- ve 7- katlı binalar oluşturulmuştur. Bina modelleri 2007 Türk Deprem Yönetmeliği'ne göre tasarlanmıştır (DBYBHY-2007, 2007). Bu binaların 12 adet gerçek yer hareketi kaydı kullanılarak her iki asal doğrultuda doğrusal elastik zaman tanım alanında analizleri yapılmıştır. Ayrıca hazırlanan binalar benzer şekilde tepki spektrumu analizine tabi tutulmuştur. Doğrusal elastik analizlerden bulunan taban kesme kuvveti ve deplasman talepleri kat sayısına göre karşılaştırılarak değerlendirilmiştir. Bu sayede tepki spektrumu analizi ve zaman tanım alanında doğrusal elastik analiz ile hesaplanan sismik talepler arasındaki farklılığının ne ölçüde olduğu tespit edilecektir.

\section{Materyal ve Metot}

\subsection{Bina Modellerinin Tanımlanması}

Mevcut betonarme yap1 stoğunun büyük bir bölümünü kapsayan düşük ve orta katlı binaları temsilen 2-, 4- ve 7- katlı yap1 modelleri hazırlanmıştır. Yap1 modellerinin oluşturulmasında 2007 Türk Deprem Yönetmeliği şartları göz önünde bulundurulmuştur. Binaların kalıp planları Şekil 1a, 1b ve 1c'de gösterilmiştir. Modellenen binalar, süneklik düzeyi yüksek sistemler olarak gözönüne alınmış, Z3 zemin grubunda ve 1. derece deprem bölgesinde yer aldığı varsayılarak tasarlanmıştır. Bina modellerinde, sadece çerçevelere sahip taşıyıcı sistem kullanılmıştır. Malzemede dayanım olarak beton basınç dayanımı için $25 \mathrm{MPa}$, donatı akma dayanımı için 420 $\mathrm{MPa}$ alınmıştır. Binaların hazırlanmasında ve analizlerinde SAP2000 programı kullanılmıştır (SAP2000, 2018). Modellenen binalar konut tipinde düşünülerek kat yüksekliği $2.80 \mathrm{~m}$ alınmıştır. Dolgu duvarların ağırlıkları dikkate alınmış olup yatay dayanıma katkısı modellere dâhil edilmemiştir. Döşemeler tasarım esnasında oluşturulmamış, döşemelerin kendi ağırlıkları ve üzerindeki yükler bu döşeme parçalarının yanındaki kirişlere düzgün yayılı yük şeklinde etkitilmiştir. Rijit diyafram kabulü yapılarak her kat seviyesi hizasında ayrı ayrı uygulanmıştır. Çalışmada kullanılan bina modellerine ait karakteristik özellikler Tablo 1'de verilmiştir. Yapısal sistemi oluşturan yap1 elemanlarına ait modellenmede çatlamış kesite ait etkin kesit rijitlikleri $(\mathrm{EI})_{\mathrm{e}}$ hesaba katılmıştır. Bu etkin rijitlik verileri, kiriş eleamanlarda 0.4EI, kolon elemanlarda ise eksenel yük seviyisenine göre 0.4EI ile 0.8EI aralığında alınmıştır (DBYBHY-2007, 2007).

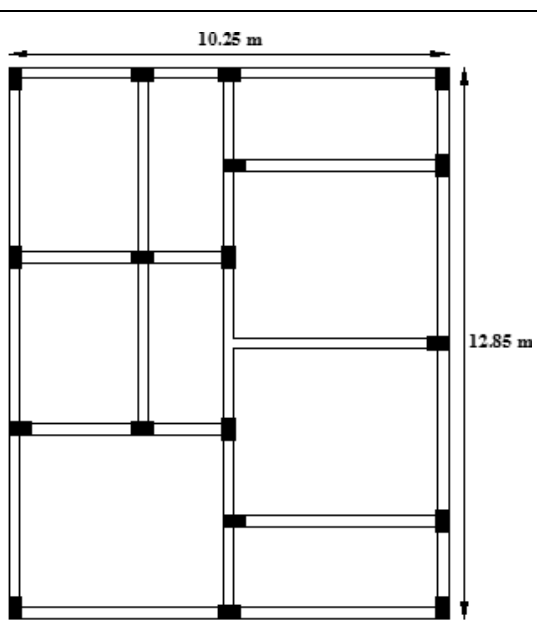

a) 2-kat 


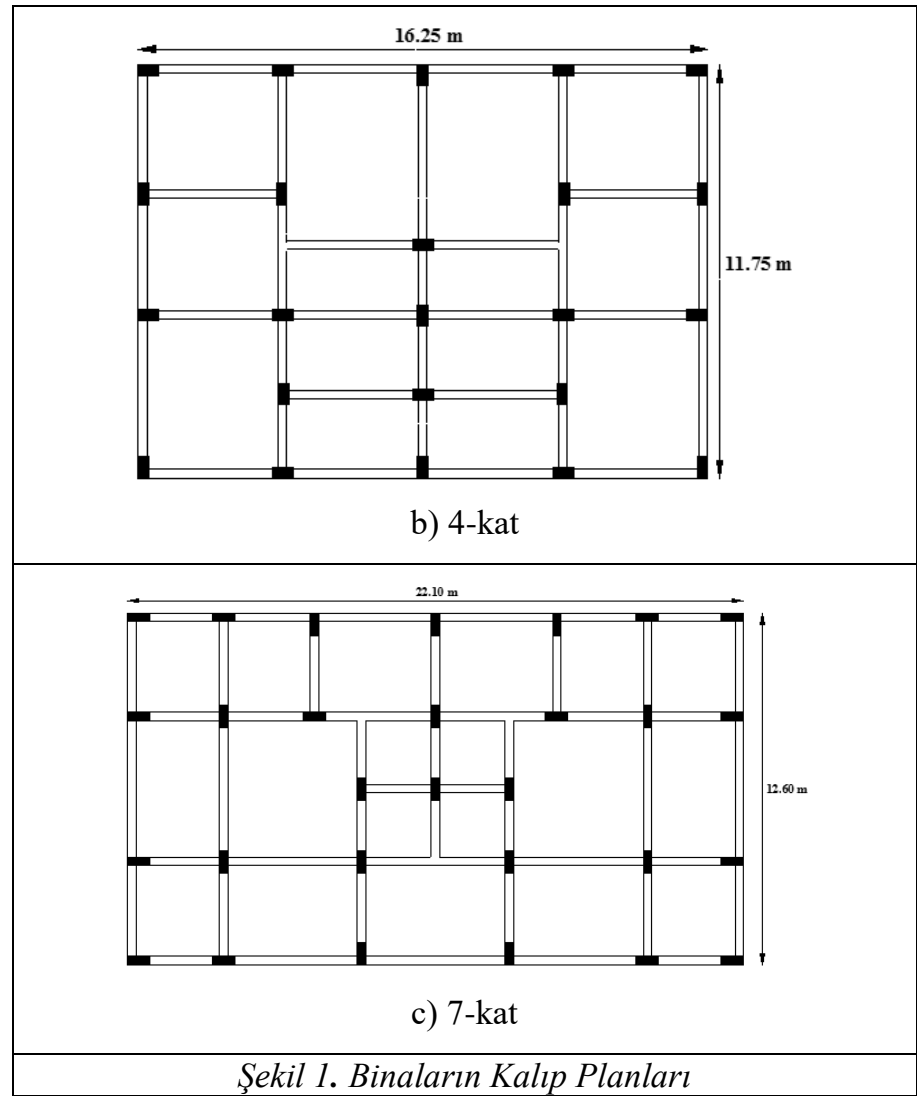

\subsection{Yer Hareketi Kayıtlarına Ait Bilgiler}

Doğrusal zaman tanım alanında gerçekleştirilen analizlerde (ZTAA) kullanılan yer hareketi kayıtları geçmişte yaşanmış depremlerden alınan farklı karakteristiklere sahip kayıtlardır (Peer, 2011). Çalışma kapsamında 2007 Türk Deprem Yönetmeliği'nde Z3 zemin grubu üzerinde 50 yılda aşılma olasılığı \%10 olan depremin standart tasarım tepki spektrumu gözönünde bulundurularak 12 adet yer hareketi kaydı ölçeklendirilmiştir. Faya normal (FN) ve faya paralel (FP) olarak iki yatay bileşeni kullanılan yer hareketi kayıtlarına ait bilgiler Tablo 2'de açıklanmıştır. Dikkate alınan kayıtların \%5 sönüm oranı için hesaplanan ivme spektrumuna ait eğriler Şekil 2'de verilmiştir. Spektrum verileri oldukça daha geniş bir aralıkta yayılırken, bina titreşim periyotlarının $0.23-0.60$ saniye değer aralığında olduğu düşünüldügüünde 12 yer hareketi kaydına ait ortalamayla yönetmelik tepki spektrumu arasında farkın fazla olmadığı görülmektedir.

\subsection{Tepki Spektrumu Analizi}

Tepki spektrumu analizi (TSA) yapının kuvvet ve deplasman talebi gibi parametrelerin hesaplanmasına olanak sağlayan doğrusal elastik zaman tanım alanında analize yakın bir analiz türüdür. Daha önce doğrusal zaman tanım alanı analizlerinde seçilen depremlerin ölçeklendirildiği tasarım spektrumu, binaların $\mathrm{X}$ ve $\mathrm{Y}$ yönlerinde tepki spektrumu analizleri için ayrıca tanımlanmıştır. Dikkate alınan binaların mod katkılarının birleştirilmesinde Karelerin Toplamının Karekökü Kuralı (SRSS) uygulanmıştır.

\section{Araştırma Sonuçları ve Tartışma}

Toplam 78 adet 3-B doğrusal elastik zaman tanım alanında analiz (ZTAA) ve tepki spektrumu analizlerinden (TSA) bulunan taban kesme kuvveti, tepe noktası ve maksimum göreli kat ötelenme oranları karşılaştırılarak değerlendirilmiştir. Binalar arasındaki değişimleri daha iyi görebilmek için analizlerden elde edilen taban kesme kuvvetleri bina ağırlığına bölünerek "taban kesme kuvveti oranı (TKKO)", tepe noktası deplasmanları bina düşey uzunluğuna bölünerek "tepe noktası ötelenme oranı (TNÖO)" ve göreli kat deplasmanları da kat yükseklik değeriyle normalize edilerek "göreli kat ötelenme oranı (GKÖO)" değişkenleri hesaplanmıştır. Çalışmada kullanılan binaların X ve Y yönlerinde 12 adet yer hareketi kaydıyla gerçekleştirilen ZTAA'dan bulunan değişkenlerin maksimum, minimum, standart sapma ve ortalama değerleri elde edilmiştir. Benzer şekilde ayrıca binaların TSA yapılarak ilgili parametrelere ait veriler bulunmuştur. Her iki analiz çeşidine göre bulunan sonuçlar arasında farkın ne derecede olduğu tespit edilerek ZTAA'nın TSA ile temsil edilebilirliği incelenmiştir.

Tablo 1. Çalışma Kapsamında Kullanılan Binalara Ait Genel Bilgiler

\begin{tabular}{c|c|c|c|c}
\hline Parametre & Yön & 2-katlı yapı & 4-katlı yapı & 7-katlı yapı \\
\hline Binanın Boyutları (m) & $\mathbf{X}$ & 10.25 & 16.25 & 22.1 \\
\hline & $\mathbf{Y}$ & 12.85 & 11.75 & 12.6 \\
\hline Bina Yüksekliği (m) & & 5.6 & 11.2 & 19.6 \\
\hline Bir Kattaki Kirişlerin Sayısı & & 26 & 36 & 44 \\
\hline Kiriş Boyutları (mm) & & $250 X 500$ & $250 \times 600$ & $300 \times 600$ \\
\hline Bir Kattaki Kolonların Sayısı & & 18 & 23 & 29 \\
\hline Kolonların Boyutları (mm) & & $300 X 500$ & $300 X 600$ & $300 X 800$ \\
\hline Tireşim Periyodu (s) & $\mathbf{X}$ & 0.25 & 0.41 & 0.59 \\
\hline & $\mathbf{Y}$ & 0.23 & 0.37 & 0.60 \\
\hline Bina Ağırlığı (kN) & & 2580 & 8328 & 21291 \\
\hline
\end{tabular}


Tablo 2. Çalışmada Analizlerde Kullanılan Yer Hareketi Kayıtlarının Özellikleri

\begin{tabular}{|c|c|c|c|c|c|c|c|c|}
\hline No & Deprem Adı & YIl & İstasyon & Bileşen & $\begin{array}{c}\text { Ölçek } \\
\text { Faktörü }\end{array}$ & $\begin{array}{c}\text { PGA } \\
(\mathrm{g})\end{array}$ & $\begin{array}{l}\mathbf{P G V} \\
(\mathbf{c m} / \mathbf{s})\end{array}$ & $\begin{array}{l}\text { Vs30 } \\
(\mathrm{m} / \mathrm{s})\end{array}$ \\
\hline 1 & \multirow{2}{*}{ Big Bear } & \multirow{2}{*}{1992} & \multirow{2}{*}{$\begin{array}{l}\text { San Bernardino- } \\
\text { E \& Hospitality }\end{array}$} & $\mathrm{FN}$ & \multirow{2}{*}{4.48} & 0.36 & 58.06 & \multirow{2}{*}{271.4} \\
\hline 2 & & & & FP & & 0.45 & 61.38 & \\
\hline 3 & \multirow{2}{*}{ Chi-Chi } & \multirow{2}{*}{1999} & \multirow{2}{*}{ CHY101 } & $\mathrm{FN}$ & \multirow{2}{*}{1.29} & 0.59 & 110.73 & \multirow{2}{*}{258.9} \\
\hline 4 & & & & FP & & 0.49 & 140.39 & \\
\hline 5 & \multirow{2}{*}{ Duzce } & \multirow{2}{*}{1999} & \multirow{2}{*}{ Duzce } & FN & \multirow{2}{*}{1.09} & 0.39 & 67.53 & \multirow{2}{*}{276} \\
\hline 6 & & & & FP & & 0.56 & 86.28 & \\
\hline 7 & \multirow{2}{*}{ Erzincan } & \multirow{2}{*}{1992} & \multirow{2}{*}{ Erzincan } & FN & \multirow{2}{*}{1.12} & 0.55 & 106.85 & \multirow{2}{*}{274.5} \\
\hline 8 & & & & FP & & 0.47 & 50.72 & \\
\hline 9 & \multirow{2}{*}{ Hector Mine } & \multirow{2}{*}{1999} & \multirow{2}{*}{ Amboy } & FN & \multirow{2}{*}{2.57} & 0.50 & 67.22 & \multirow{2}{*}{271.4} \\
\hline 10 & & & & FP & & 0.52 & 56.21 & \\
\hline 11 & \multirow{2}{*}{ Imperial Valley } & \multirow{2}{*}{1979} & \multirow{2}{*}{$\begin{array}{l}\text { EC County } \\
\text { Center FF }\end{array}$} & FN & \multirow{2}{*}{2.06} & 0.37 & 112.07 & \multirow{2}{*}{192.1} \\
\hline 12 & & & & FP & & 0.46 & 88.36 & \\
\hline
\end{tabular}

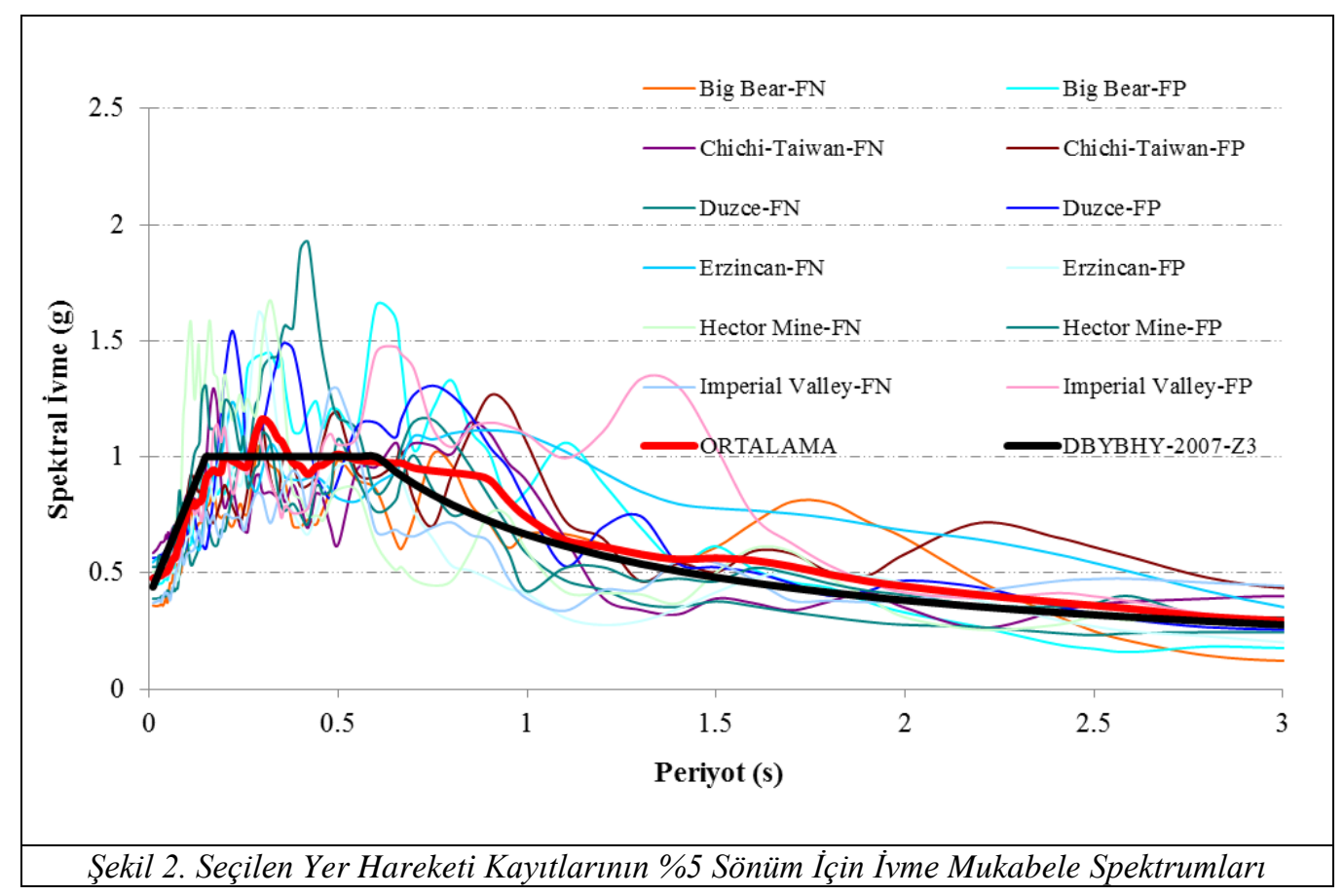

ZTAA ve TSA sonuçlarına göre 2-, 4- ve 7- katlı binalara ait TKKO değerleri Tablo 3'de gösterilmiştir. ZTAA 'dan bulunan ortalama değerlere ve TSA sonuçlarına bakıldığında her iki analiz için 2- ve 7- katlı binalara ait TKKO değerleri birbirine yakın iken 4-katlı binaya göre nispeten az hesaplanmıştır. ZTAA'dan elde edilen TKKO değerleri TSA sonuçlarına göre 2ve 7 - katlı binalarda sirasıly \%12 ve \%14 fazla olurken 4 - katlı binada birbirine çok yakındır.

Şekil 3'te görüldüğü üzere ZTAA'dan elde edilen taban kesme kuvveti taleplerinin geniş bir aralığa yayıldığı ve bunlara ait maksimum/minimum oranının 1.8 ile 2.9 arasında değişen değerlere çıkabildiği hesaplanmıştır. Ayrıca ZTAA'dan bulunan ortalama TKKO'nun TSA sonuçlarına göre yakın ve yüksek olması tasarıma esas olan taban kesme kuvveti düşünüldüğünde ZTAA'nın güvenli tarafta kaldığı söylenebilir.

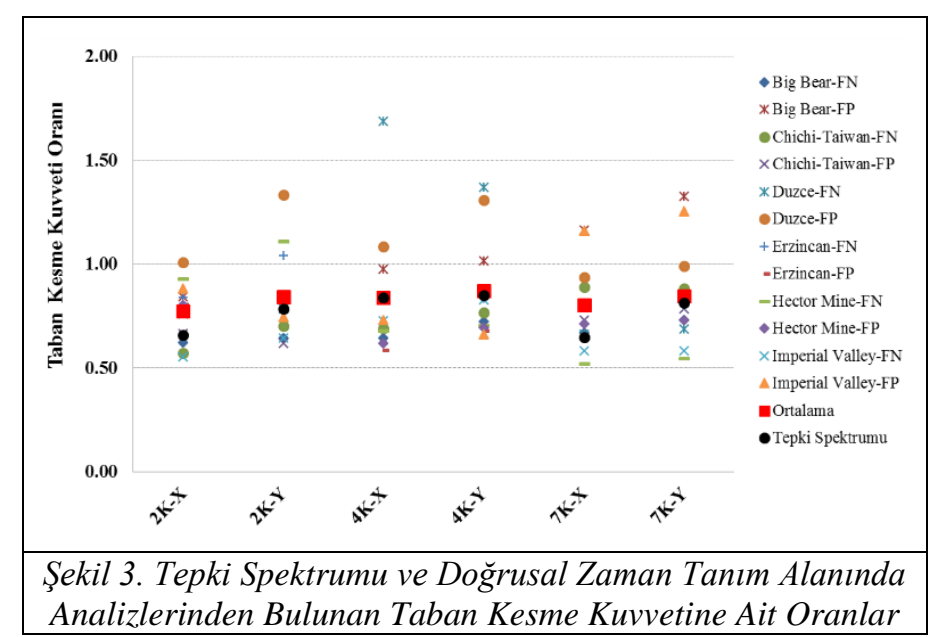


Tablo 3. 2-, 4-ve 7- katlı Yapı Modellerinin Taban Kesme Kuvveti Oranı (TKKO) Değerleri

\begin{tabular}{lcccccc}
\hline \multirow{2}{*}{ Depremler } & \multicolumn{2}{c}{ 2-katl1 yap1 } & \multicolumn{2}{c}{ 4-katl1 yap1 } & \multicolumn{2}{c}{ 7-katl1 yap1 } \\
\cline { 2 - 7 } & $\mathrm{X}$ & $\mathrm{Y}$ & $\mathrm{X}$ & $\mathrm{Y}$ & $\mathrm{X}$ & $\mathrm{Y}$ \\
\hline Big Bear-FN & 0.62 & 0.64 & 0.65 & 0.73 & 0.67 & 0.73 \\
Big Bear-FP & 0.84 & 0.85 & 0.98 & 1.02 & 1.17 & 1.33 \\
Chichi-FN & 0.57 & 0.70 & 0.69 & 0.77 & 0.89 & 0.88 \\
Chichi-FP & 0.67 & 0.62 & 0.83 & 0.86 & 0.73 & 0.78 \\
Duzce-FN & 0.76 & 0.79 & 1.69 & 1.37 & 0.66 & 0.69 \\
Duzce-FP & 1.01 & 1.33 & 1.09 & 1.31 & 0.94 & 0.99 \\
Erzincan-FN & 0.84 & 1.04 & 0.83 & 0.83 & 0.80 & 0.80 \\
Erzincan-FP & 0.81 & 0.78 & 0.59 & 0.68 & 0.80 & 0.84 \\
Hector-FN & 0.93 & 1.11 & 0.68 & 0.70 & 0.52 & 0.55 \\
Hector-FP & 0.80 & 0.84 & 0.62 & 0.69 & 0.71 & 0.73 \\
Imperial-FN & 0.55 & 0.65 & 0.73 & 0.83 & 0.58 & 0.58 \\
Imperial-FP & 0.88 & 0.75 & 0.73 & 0.66 & 1.16 & 1.26 \\
\hline Maksimum & 1.01 & 1.33 & 1.69 & 1.37 & 1.17 & 1.33 \\
Minimum & 0.55 & 0.62 & 0.59 & 0.66 & 0.52 & 0.55 \\
Standart Sapma & 0.14 & 0.22 & 0.30 & 0.24 & 0.21 & 0.24 \\
Ortalama & 0.77 & 0.84 & 0.84 & 0.87 & 0.80 & 0.85 \\
\hline Tepki Spektrumu & 0.66 & 0.79 & 0.84 & 0.85 & 0.65 & 0.82 \\
\hline
\end{tabular}

ZTAA ve TSA sonuç değerlerine göre 2-, 4- ve 7- katlı binalara ait TNÖO değerleri Tablo 4'de verilmiştir. ZTAA ve TSA'dan elde edilenlere bakıldığında her iki analiz türünde de kat sayısının artışıyla doğru orantılı olarak TNÖO verilerinin yükseldiği gözlemlenmiştir. Bulunanlara göre TNÖO değerleri açısından değerlendirildiğinde her iki analizde de ortak olarak 7katlı binaların daha riskli olduğu anlaşılmaktadır. Ortalama ZTAA bulguları ile TSA sonuçları kıyaslandığında 2- ve 4- katlı binalarda farklar sınırlı düzeyde kalırken özellikle 7- katlı binanın X yönünde \%19'luk bir fark ortaya çıkmıştır.

Tablo 4. 2-, 4- ve 7- katlı Yapı Modellerinin Tepe Noktası Ötelenme Oranı (TNÖO) Değerleri (\%)

\begin{tabular}{lcccccc}
\hline \multirow{2}{*}{ Depremler } & \multicolumn{3}{c}{ 2-katlı yap1 } & \multicolumn{2}{c}{ 4-katl1 yap1 } & \multicolumn{2}{c}{ 7-katl1 yap1 } \\
\cline { 2 - 7 } & $\mathrm{X}$ & $\mathrm{Y}$ & $\mathrm{X}$ & $\mathrm{Y}$ & $\mathrm{X}$ & $\mathrm{Y}$ \\
\hline Big Bear-FN & 0.22 & 0.20 & 0.34 & 0.31 & 0.45 & 0.51 \\
Big Bear-FP & 0.31 & 0.26 & 0.52 & 0.45 & 0.88 & 0.99 \\
Chichi-FN & 0.20 & 0.22 & 0.34 & 0.32 & 0.59 & 0.55 \\
Chichi-FP & 0.23 & 0.18 & 0.42 & 0.40 & 0.51 & 0.54 \\
Duzce-FN & 0.27 & 0.24 & 0.92 & 0.61 & 0.49 & 0.50 \\
Duzce-FP & 0.36 & 0.41 & 0.57 & 0.58 & 0.66 & 0.68 \\
Erzincan-FN & 0.31 & 0.33 & 0.42 & 0.35 & 0.53 & 0.52 \\
Erzincan-FP & 0.27 & 0.24 & 0.32 & 0.31 & 0.55 & 0.58 \\
Hector-FN & 0.33 & 0.35 & 0.37 & 0.35 & 0.36 & 0.37 \\
Hector-FP & 0.30 & 0.26 & 0.33 & 0.32 & 0.47 & 0.44 \\
Imperial-FN & 0.20 & 0.20 & 0.40 & 0.35 & 0.40 & 0.40 \\
Imperial-FP & 0.30 & 0.22 & 0.36 & 0.31 & 0.81 & 0.84 \\
\hline Maksimum & 0.36 & 0.41 & 0.92 & 0.61 & 0.88 & 0.99 \\
Minimum & 0.20 & 0.18 & 0.32 & 0.31 & 0.36 & 0.37 \\
Standart Sapma & 0.05 & 0.07 & 0.17 & 0.11 & 0.16 & 0.18 \\
Ortalama & 0.28 & 0.26 & 0.44 & 0.39 & 0.56 & 0.58 \\
\hline Tepki Spektrumu & 0.25 & 0.25 & 0.47 & 0.39 & 0.47 & 0.60 \\
\hline & & & & & &
\end{tabular}

ZTAA'dan bulunan TNÖO sonuçları, binalarda çok farklı seviyede deplasman taleplerinin oluşabileceğini göstermektedir (Şekil 4). TSA'ya ait TNÖO verilerinin ZTAA'nın minimum ile maksimum değerler aralığında kaldığı, 7- katlı binanın $X$ yönü hariç ZTAA ortalamalarına oldukça yakın olduğu Şekil 4'te daha açık görülmektedir. Başka bir ifadeyle, TSA'nın ZTAA'ya ait ortalama değerleri çoğunlukla yakalayabildiğini söylemek mümkündür.

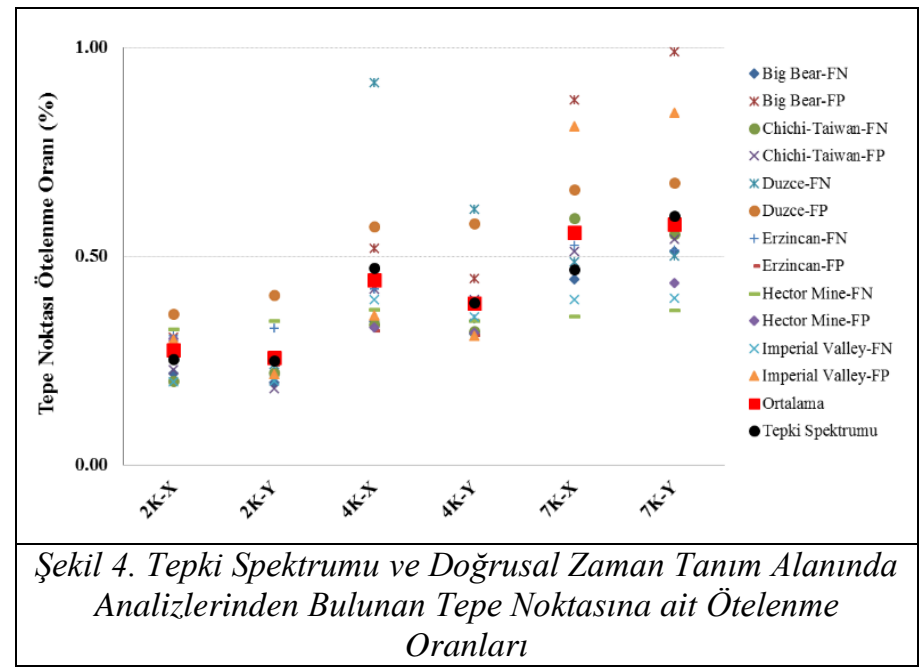

Analizlerden bulunan 2-, 4- ve 7- katlı yapılara ait GKÖO değerleri Tablo 5'de gösterilmiştir. TNÖO bulgularına benzer olarak kat sayısının artması ile GKÖO verilerinin de arttığ sonucuna varılmıştır. GKÖO verileri dikkate alındığında 7-katlı binanın değerleri 2- ve 4- katlı bina değerlerine bölündüğünde sırasıyla ZTAA'nın ortalama verileri dikkate alındığında 2.7, 1.5 ve TSA'da ise 2.7, 1.3 oranları bulunmuştur. ZTAA'dan bulunan ortalama değerler ile TSA sonuçları karşılaştırıldığında 2- ve 7katlı binalarda sırasıyla \%9 ve \%22'e ulaşan farklar görülürken 4- katlı binada \%6 gibi sınırlı miktarda bir fark elde edilmiştir.

Tablo 5. 2-, 4- ve 7- katlı Yapı Modellerinin Göreli Kat Ötelenme Oranı (GKÖO) Değerleri (\%)

\begin{tabular}{|c|c|c|c|c|c|c|}
\hline \multirow{2}{*}{ Depremler } & \multicolumn{2}{|c|}{ 2-katlı yap1 } & \multicolumn{2}{|c|}{ 4-katl1 yap1 } & \multicolumn{2}{|c|}{ 7-katl1 yap1 } \\
\hline & $\mathrm{X}$ & $\mathrm{Y}$ & $\mathrm{X}$ & $\mathrm{Y}$ & $\mathrm{X}$ & $\mathrm{Y}$ \\
\hline Big Bear-FN & 0.24 & 0.23 & 0.47 & 0.42 & 0.64 & 0.72 \\
\hline Big Bear-FP & 0.34 & 0.30 & 0.72 & 0.60 & 1.20 & 1.36 \\
\hline Chichi-FN & 0.22 & 0.25 & 0.46 & 0.44 & 0.87 & 0.85 \\
\hline Chichi-FP & 0.25 & 0.22 & 0.59 & 0.53 & 0.72 & 0.78 \\
\hline Duzce-FN & 0.30 & 0.28 & 1.26 & 0.83 & 0.67 & 0.71 \\
\hline Duzce-FP & 0.39 & 0.47 & 0.79 & 0.79 & 0.94 & 0.98 \\
\hline Erzincan-FN & 0.33 & 0.37 & 0.58 & 0.47 & 0.77 & 0.77 \\
\hline Erzincan-FP & 0.30 & 0.28 & 0.45 & 0.42 & 0.79 & 0.82 \\
\hline Hector-FN & 0.37 & 0.39 & 0.50 & 0.47 & 0.50 & 0.52 \\
\hline Hector-FP & 0.32 & 0.30 & 0.45 & 0.43 & 0.70 & 0.70 \\
\hline Imperial-FN & 0.22 & 0.23 & 0.54 & 0.48 & 0.58 & 0.58 \\
\hline Imperial-FP & 0.34 & 0.26 & 0.50 & 0.41 & 1.17 & 1.26 \\
\hline Maksimum & 0.39 & 0.47 & 1.26 & 0.83 & 1.20 & 1.36 \\
\hline Minimum & 0.22 & 0.22 & 0.45 & 0.41 & 0.50 & 0.52 \\
\hline Standart Sapma & 0.06 & 0.08 & 0.23 & 0.14 & 0.22 & 0.25 \\
\hline Ortalama & 0.30 & 0.30 & 0.61 & 0.52 & 0.80 & 0.84 \\
\hline Tepki Spektrumu & 0.27 & 0.28 & 0.65 & 0.53 & 0.65 & 0.83 \\
\hline
\end{tabular}


Şekil 5'den anlaşılacağı üzere, ZTAA'dan bulunan 2- katlı binaya ait GKÖO verilerinin 4- ve 7- katlı bina sonuçlarına göre daha dar bir aralıkta değiştiği gözlemlenmiştir. TNÖO sonuçlarına benzer bir eğilimde, TSA'nın GKÖO verilerinin ZTAA'dan elde edilen değerlerinin dışına çıkmadan bunlar arasında yer aldığı, ZTAA ortalamalarına yaklaştığı Şekil 5'te görülmektedir.



Şekil 5. Tepki Spektrumu ve Doğrusal Zaman Tanım Alanında Analizlerinden Bulunan Göreli Kat Ötelenme Oranlart

Ortalama GKÖO verileri TNÖO değerlerine bölündüğünde 2-, 4- ve 7- katlı binalarda sirasiyla ZTAA'da $1.12,1.36$ ve 1.44 oranları bulunurken TSA'da ise 1.09, 1.36 ve 1.39 oranları elde edilmektedir. Buna göre her iki analizde de artan kat sayısına bağlı olarak GKÖO ile TNÖO değerleri arasındaki farkın açıldığı anlaşılmaktadır. ZTAA'dan bulunan TKKO'ya ait standart sapma verilerinin TNÖO ile GKÖO değerlerine göre daha yüksek olduğu, katlar arasında yapılan değerlendirmede ise 2- katlı binanın taban kesme kuvveti ve deplasman taleplerinin standart sapma verilerinin 4- ve 7- katlı binalara göre daha düşük olduğu belirlenmiştir. ZTAA sonuçlarına göre taban kesme kuvveti ve deplasman taleplerine ait maksimum/minimum oranlarının 1.8 ile 2.9 arasında değişkenlik gösterdiği sonucuna ulaşılmıştır.

\section{Sonuç}

Düşük ve orta katlı mevcut betonarme binaların yansıtılması için 2-, 4- ve 7- katlı yapılar 2007 Türk Deprem Yönetmeliği dikkate alınarak oluşturulmuştur. Daha sonra, 3-B bina modelleri $X$ ve $Y$ doğrultularında doğrusal elastik zaman tanım alanı ve tepki spektrumu analizlerine tabi tutulmuştur. Toplam 78 analiz sonucuna göre taban kesme kuvveti, tepe noktası ötelenme ve maksimum göreli kat ötelenme oranları hesaplanmıştır. Doğrusal elastik zaman tanım alanı ve tepki spektrumu analizlerinin bulunan parametreler üzerindeki etkileri araştırılarak değerlendirmeler yapılmıştır. Çalışmadan elde edilen sonuçlar aşağıda açıklanmaya çalışılmıştır.

$>$ Taban kesme kuvveti oranlarına bakıldığında doğrusal elastik zaman tanım alanı analizlerinden bulunan değerler tepki spektrumu analizi verilerine göre 2- ve 7- katlı binalarda sirasiyla \%10-\%15 dolaylarında fazla hesaplanırken 4- katlı binada farklar sınırlı kalmıştır.

> Her iki analizde de kat sayısının artmasıyla tepe noktası ötelenme oranlarının arttığı ve tepe noktası ötelenme taleplerine göre 7- katlı binaların daha riskli olduğu sonuçlarına ulaşılmıştır.

> İki analiz türünden elde edilen göreli kat ötelenme oranları arasındaki farklar tepe noktası ötelenme sonuçlarına benzer olarak değişmektedir. Ayrıca göreli kat ötelenme ve tepe noktası ötelenme oranları arasındaki farkların kat sayısının artışıyla birlikte her iki analiz için de yükseldiği gözlemlenmiştir.

> Doğrusal elastik zaman tanım alanı sonuçlarına göre özellikle 4- katlı binaya ait taban kesme kuvveti ve deplasman taleplerinin tepki spektrumu analiz verilerine çok yakın olduğu gözlemlenmiştir. Bu durum, 4- katlı binaya ait periyot değerlerinin bulunduğu spektrum sabit ivme bölgesinde seçilen depremlerin ivme kayıtlarına ait spektral ivme değerlerin ortalamasının dikkate alınan tasarım spektrumuna yakın olmasıyla açıklanabilir.

$>$ Tepki spektrumu analizinin doğrusal elastik zaman tanım alanı analizlerine ait ortalama değerleri yaklaşık olarak tahmin edebildiği ifade edilebilir. Bilhassa zaman tanım alanı analizlerinde ölçeklendirilmiş deprem ivme kayıtlarının kullanılmasının iki analiz türüne ait sonuçları birbirine yaklaştırdığı düşünülmektedir. Aksi takdirde ölçeklendirme yapılmamış rastgele seçilen deprem ivme kayıtlarının, sonuçları iki analiz türü açısından birbirinden uzaklaştırabileceği unutulmamalıdır. Buna ilave olarak seçilen depremlere ait spektral ivme değerlerinin büyüklüğü ve farklı özellikteki (ileri yönlenme etkisi vb.) deprem ivme kayıtları zaman tanım alanı analiz sonuçlarına doğrudan etki edeceğinden analizler arasındaki fark bunlara bağlı olarak değişebilir.

$>$ Depremin binaya hangi yönde etki edeceği önceden bilinemediği için binaların tasarımı aşamasında kolonların uzun boyutlarının binanın her iki yönünde eşit dağıtılmasına çalışılmıştır. Bundan dolayıdır ki her iki analiz çeşidinden bulunan sonuçlarda $\mathrm{X}$ ve $\mathrm{Y}$ yönü arasında ciddi bir fark oluşmamıştır. Bunun dışında kullanılan binaların kalıp planlarına ait boyutlar arasında farkın çok bulunmaması ve bunların dikdörtgen geometriye sahip olması da sonuçların doğrultular açısından farkın açılmamasını sağlamıştır.

\section{Kaynakça}

İnel, M., Önür, Ö., Özmen, H.B., \& Çelik S. (2011). İleri yönlenmeli deprem kayıtları etkisindeki mevcut betonarme binaların deplasman taleplerinin doğrusal elastik zaman tanım alanında analizle değerlendirilmesi”, Yedinci Ulusal Deprem Mühendisliği Konferansı, İstanbul.

Önür, Ö. (2011). Düşük ve orta yükseklikteki betonarme yapıların deplasman taleplerinin doğrusal elastik zaman tanım alanında analizle belirlenmesi, Pamukkale Üniversitesi Fen Bilimleri Enstitüsü, yüksek lisans tezi.

Özer, E., Kamal, M., \& İnel, M. (2017). Comparison of linear and nonlinear seismic behavior of 2D and 3D rc buildings. International Journal of Engineering \& Applied Sciences, 9(4): $17-27$.

Özdemir, S. (2016). Bina tipi yapılarda sismik izolasyon etkinliğinin incelenmesi, Orta Doğu Teknik Üniversitesi Fen Bilimleri Enstitüsü, yüksek lisans tezi.

Velioğlu, E. (2017). Mevcut betonarme yapılarda kullanılan değerlendirme yöntemlerinin tutarlılığı, Bitlis Eren Üniversitesi Fen Bilimleri Enstitüsü, yüksek lisans tezi.

DBYBHY-2007. (2007). Deprem Bölgelerinde Yapılacak Binalar Hakkında Yönetmelik, Bayındırlık ve İskân Bakanlığı, Ankara.

SAP2000 V-20. (2018). Integrated finite element analysis and design of structures basic analysis reference manual. Computers and Structures Inc., Berkeley (CA, USA).

Peer. (2011). Pacific Earthquake Engineering Research Center, http://peer.berkeley.edu (Erişim tarihi: 10 Ekim 2021). 